\title{
That the People May Live: The Cowlitz Tribe's Journey of Peace and Justice
}

\author{
Eugene A. Wiggins \\ Cowlitz Indian Nation of Washington State, United States of America
}

\begin{abstract}
In an age of conflict and violence, the human family seeks peace-building paradigms. 'Wisdom' in traditional Native American culture provides a lens for exploring peace psychology. Native American culture understands 'wisdom' to be, 'that the people may live'. Living implies love of life, love of others' lives, and the right to life and dignity. Here lies wisdom, that people may live with peace and justice. The Cowlitz Indians of western Washington, United States (US), traditionally, based constructive relations on the wisdom of kinship values, an ethic of generosity and reciprocity towards the wider community. Despite land loss and assimilation efforts of the dominant society, the US federal government finally recognised the Cowlitz Nation. This long awaited acknowledgment, won through adherence to traditional wisdom and values, has provided affirmation 'that the people may live'.
\end{abstract}

\author{
Keep \\ a few embers \\ from the fire that used \\ to burn in your village, some day \\ go back so all can gather again \\ and rekindle a new flame, for a new life in a changed world. \\ Chief Dan George (1974, p. 13)
}

Join me as we take a journey to a special place: a cultural space where peace and equality walk hand in hand; a place where community and togetherness are part of the sacred dance of all things. Sit down by a quiet river whose source is a glacier high on the slopes of Tahoma (the familiar Indian name for Mount Rainier). Today, the river is known as the Cowlitz River. It flows gently through meadows filled with wildflowers, the songs of birds and the aroma of evergreen forests towering a short distance away. View a deer sipping the bank water. Hear the clack of a heron and see salmon returning to their place of birth after surviving a long journey in ocean waters. Watch in awe as the dynamics of the natural process relate to everything around you, and you feel a part of the great mystery.

This was the aboriginal land of the Cowlitz Nation that they had peacefully inhabited for many centuries before the intrusion of Europeans. It was an area consisting of approximately one million acres of highly desirable land stretching from the Columbia River northward to the foothills of Mt Rainier, and from the Interstate Highway I-5 corridor eastward to the crest of the Cascade Mountains. It is no wonder that the Cowlitz people were in great pain when they were forced to leave their beautiful aboriginal land.

The land permeated every aspect of tribal life and provided the background for the oral traditions that kept their history alive. These traditions were, and still are, important, because for the Cowlitz people that is, 'how you know; how you belong; how you know you belong. To understand something of the Cowlitz people's anguish, it is necessary to go back to a pivotal point in the tribe's history and walk with them to the present time. On this journey we will encounter mingling shadows of yesteryear, mixed with the reality of change.

We begin the journey in the year 1792, when the American Captain Robert Gray entered the mouth of the fabled 'great river of the west' and named it for his ship, 'The Columbia'. Gray's report of his findings prompted Thomas Jefferson, in 1804, to send the Corps of Discovery led by Lewis and Clark, to gain more knowledge of the region. The final leg of that expedition, down the Columbia River to the Pacific Ocean, gave the United States a strong stake in the north-western lands.

The earliest historical accounts of the Cowlitz began when Astorians of the Pacific Fur Company began arriving from Fort Astoria in 1811. 'The second engagement 
between the Cowlitz and non-Indians took place after the North West Company, which had bought out the Pacific Fur Company in 1813 sent trappers and hunters, including Iroquois Indians, up the Cowlitz River' (Irwin, 1994, p. 11). The foreigner's interventions into Cowlitz way of life set in motion rapid changes that would test the wisdom and perseverance of the Cowlitz people for generations to come.

In one of Captain Gray's reports, mention was made regarding the abundance of beavers in the lower Columbia River region. As a result of Gray's discovery, fur trappers and traders began arriving to establish and conduct fur trading for European markets. During the 1840s the British Hudson's Bay Company, led by Dr John McLoughlin, became the dominant force in this economy. To establish a commanding presence in the north-west region, the American Government encouraged Americans to join the quest for furs. To counter the influx of American trappers, the Hudson Bay Company hired French Canadians, skilled in trapping and preparing beaver pelts, to come and trap beavers. As a result of the excessive trapping, the beaver population began dwindling. The British hoped their strategy of reducing the beaver resource would discourage Americans from trapping, and allow the British to control the region. However, the 1840 s saw a continuing influx of Americans seeking the bounty that the Oregon Territory provided. Disputes for control of the territory between American settlers and the Hudson Bay Company were finally resolved in the 1846 Oregon Treaty, in which Great Britain gave up claims to the region. The Oregon Territory was established in 1849.

Miners, stockmen and farmers continued to arrive in large numbers in the Oregon Territory, and this prompted the United States Government to send representatives to the region. Their duties were to enlarge land claims for the government and the colonists, to settle land claim disputes, to survey the route for a railroad, to reserve lands for the Indians and to organise and develop the reservation system. Technological and social changes introduced by the various cultural conventions were imposed upon traditional communities. Cultural structures that maintained homogeneity within tribal borders were being impacted. With political manoeuvring, changes were being thrust upon the aboriginal people.

Congress established the Oregon Donation Land Act in 1850 allowing a male settler to claim 160 acres for himself and another 160 acres for his wife. The Donation Act was specifically designed to induce settlements on public domain in distant or dangerous portions of the nation. Despite the uncertainty these adventures posed, R. K. Wright mentions that a steady influx of eager settlers and entrepreneurs were soon crossing the Columbia River seeking their fortunes in what was to become the Washington Territory (Wright,
1991). This granting of land was in violation of the Indian Intercourse Law of 1834 requiring cooperation between Indian groups and the Federal Government authorising who could settle in Indian country. There was no explanation of the means used to determine what Indian territories could be invaded and claimed without Indian titles being removed. Congress, by virtue of the Donation Act, opened Indian lands for settlement, thus awarding land that was not theirs to give away. Settlers simply came into lands belonging to the Cowlitz and adjoining tribes and made their clearings. Quinn (1999) mentions that in the European mind the taking of land in this manner was not stealing, but merely putting the land to good use since the natives were letting the land go to waste.

The appointed Washington Territorial Governor and Superintendent of Indian Affairs, Isaac Stevens, upon reaching the Washington Territory, reacted immediately to the conflict being created by the settlers land claims. Stevens wrote to the office of Indian Affairs in late 1853, and expressed urgency for making treaties with Indian tribes west of the Cascade Mountains. In 1854, Governor Stevens received instructions from the Federal Government to buy out Indian rights through the negotiation of treaties.

A period of treaty making began in which the tribes in Washington Territory were placed on reservations. In 1854-1855 Governor Stevens, in an expeditious procedure relocated the Indians of western Washington, by negotiating four major treaty areas: Point Elliot, Point No Point, Neah Bay and Medicine Creek. The Chehalis River Treaty Council was to be the final treaty session to be negotiated in his whirlwind circuit of tribal locations.

Stevens met with tribal leaders representing the Cowlitz and other neighbouring tribes, but the outcome was a failure. Governor Stevens was asking the tribal leaders to sign away their rights, title, and interests in all of their lands. He offered one large reservation to be located on the coast for all of the tribes represented at the treaty session. Chief Kishkok and elders of the Cowlitz tribe refused to abandon the rivers and homeland they had occupied for centuries. Governor Stevens had little patience for discussing the objections to his proposal with the people he referred to as, 'My Children'. The Cowlitz' request for a reservation in their country did not meet the requirements of the treaty Stevens had already written. His disregard for the will of the Cowlitz people ended the negotiations without a treaty being signed.

The Cowlitz felt that by not signing the Chehalis River Council Treaty they had not given up anything. The tribal representatives expected further negotiations because Governor Stevens had indicated he would return and meet further with the tribe. He did not. Following the failed treaty session George Gibbs, who served as an assistant to Stevens, commented on the Cowlitz disruptive circumstances resulting frm the loss 
of land. He said that 'the Cowlitz, a once numerous and powerful tribe, are now insignificant and fast disappearing. The few bands remaining are intermingled with those of the Upper Chilhalis. According to the best estimate obtained, the two united are not over one hundred and sixty-five in number, and are scattered in seven parties between the mouth of the Cowlitz and Satsop' (Cowlitz Indian Tribe, 2006, p. 53)

The first governor of the new Washington territory thought he had brought peace through his treaty making, but his inability to enforce the terms of the treaty brought about hostilities. A general Indian uprising, known as the Indian Wars of 1855-1856, occurred almost immediately after the treaties were signed. Disgruntled Indians and non-Indians were not satisfied with the arrangements of the treaties, and the US Army was called in to settle the disputes.

The Cowlitz tribe never fought against the government troops under the command of Captain Sidney S. Ford, Jr., but actually gave backing to the military effort. As a result of their cooperation, the Cowlitz were given the promise of a reservation if they remained peaceful. However, to insure that the Cowlitz would continue to be friendly, a large number of the tribe was confined at Fort Vancouver. In returning home from their internment, the people found that their horses and other property had been destroyed. The promise made to the Cowlitz tribe regarding a reservation was soon forgotten.

On March 20, 1863, a Presidential proclamation directed that the Cowlitz lands be sold, thereby depriving the Cowlitz of its original Indian title without their consent and without compensation. The government's decision constituted an act of injustice toward the Cowlitz people. Ironically, the tribes who fought against the US were awarded land while the Cowlitz, who supported the government, received nothing. The people were left with three alternatives: to go to another tribe's reservation and be wards of the government; to work at slave wages for white settlers; or to strike out on their own and to be self-sufficient. Looking back on the resoluteness exhibited by the Cowlitz leaders at the treaty session, it can be seen that their bold and wise determination enabled the people to live with a choice, as opposed to the way government caretakers thought they should live.

Though fires no longer burned brightly in former villages, hope remained that the Cowlitz tribe would once again return to their homeland and rekindle new flames. The deeply engrained cultural coding bequeathed to following generations still resided in the hearts of the people. Scott Momaday refers to this as, 'memories in the blood' (Weaver, 1998, p. 7). Reflecting on the tribe's history would continue to remind the people of an injustice that needed to be corrected. However, remembering the past would come to mean more than nurturing painful remorse; by honest reflection the present was to be culti- vated and a vision was sought for making changes in the tribe's future. And the Cowlitz tribe's situation was to undergo numerous changes.

In making necessary changes the Cowlitz people endeavoured to keep their cultural ways intact. They wanted to avoid what happens to cultures that refuse to change: they become the dead and petrified kind. By maintaining memories of the past, and sustaining their cultural traditions, the tribe would preserve its identity in the face of constant change. To successfully meet challenges initiated by ever changing circumstances, the people would need to: 1 , rely on ancient wisdom; 2 , retain community connections, and 3 , sustain hope in troubled times.

\section{Wisdom — Weaving a New Blanket}

The Cowlitz tribal way of life has been a long history of establishing communal wisdom from the experiences of what works and what doesn't work. Traditional ways allowed the tribe to function well, and gave stability and guidance to the people as they sought new sources of strength for tribal existence. The word 'Cowlitz' has as its meaning 'seeking the medicine spirit'; the medicine or power enabled the tribe to exist for centuries by maintaining an ecological, spiritual, personal, and social relationship with all living things. In order to perpetuate this balanced and harmonious life, the accumulated wisdom of the tribe needed to be passed on to following generations as a means of cultural survival, necessitating the ability to speak wisely not only to one, but to many generations beyond them. Chief Dan George expressed this view when he said, 'The wisdom and eloquence of my father I passed on to my children, so they too acquired faith, courage, generosity, understanding, and knowledge in the proper way of living' (George, 1974, p. 66).

Unfortunately, much of the former sources of Native American wisdom has not survived the relentless and careless uprooting of their cultures. By controlling and conquering, European invaders made a determined effort to eclipse whatever was non-European. The Western society's conceit of dominion over nature transcended the natural world, and surpassed the experiences of tribal people by making their primitive ways appear inferior to priorities of civilised people. Consequently, Daniel Quinn in his book 'Beyond Civilization' maintains that, in regard to the natural world, the Western motivated civilised structure has progressed to becoming a culture of maximum harm. He believes that the United States represents the high point of maximum affluence that modern civilisation has reached. He states:

There's no place on earth where people have more, use more, or waste more than in the United States (...) this is what I call 'the culture of maximum harm,' a culture in which all members are dedicated to attaining the high point of maximum affluence (and to forever raising the high point of maximum affluence. (Quinn, 1999, p. 109) 
The Cowlitz and other tribal groups have understood the wisdom of having their lives being intimately connected to their ancestral lands and to the community of all life. Their sense of community included an awe and respect for the natural world and the importance it has for human survival. What many are discovering today is that there are valuable lessons of wisdom to be learned from those who walk in the sacred pathway of all living things. The values and ideas of traditional people have not been lost, despite their suppression for many generations.

Like grass pushing through the blacktop and cracks in the concrete of industrial civilisations, the wisdom of native peoples of the Americas stands to enlighten the modern world. An examination of tribal people's life-ways suggests benefits of ancient wisdom that can be applied to our human condition that presently is in a state of separation and disharmony. Carla Berkedal in her article, 'Native American Voices', makes the observation:

\begin{abstract}
Our culture is coming to be aware that Native American spiritualities and traditions have a kind of wisdom our culture does not have. Our infatuation with technology, our relentless imperatives of growth and expansion, and our arrogant assumption that God made the earth solely for humans - comprise a worldview we realise needs correcting, healing and transforming. Consequently, we as persons of the dominant culture can benefit by respectfully listening, and learning what the First Peoples of this continent have to teach us. (Berkedal, 1998, p. 1)
\end{abstract}

The perceived sophisticated and advanced cultures of today have paid a great price for their advancement. The progressive societies that have invested heavily in market-led profit making and material progress reveal features of disharmony in their lives, their communities, and their institutions. Daily news reports disclose a world in crisis. The increase of violence, warfare, serial murder, mental illness, suicide, drug addiction, and overcrowded prisons are some indicators of civilised societies' imbalance. Robert N. Bellah et al., in commenting on the search for meaning in modern America said, 'We seem to be hovering on the very brink of disaster, not only from international conflict but from the internal incoherence of our own society. In thinking about what has gone wrong, we need to see what we can learn from our traditions, as well as from the best currently available knowledge' (Bellah, 1989, p. 462).

The disharmony in the present society signifies a need for both modern and ancient cultures to engage in sharing mutual wisdom in order that the global community can be bound together through moral reciprocity, respect and restraint. Thus, in the search for a paradigm of peace and justice in today's social structure, it is vital to have not only a vision for the future but also the ability to look back. Looking back uncovers wisdom of the 'Old Ways' that have enabled tribal people to exist in harmony with the natural world, while demonstrating a respect for all life. Those of the traditional non-Indian world can, if they look back, find correspondences of ancient wisdom within their culture since their culture was once a traditional one as well. Using a conjugated search for wisdom, modern societies can fashion new blankets of understanding when weaving those ancient threads of wisdom together with new strands of discovered truths.

\section{Community - Connecting with All Things}

The venture of choosing a new paradigm for promoting greater peace and justice in the present world involves taking a different path than one manipulated by corporate profit making. To make an inquiry for such a paradigm does not require a dash at full speed, but is a contemplation that takes us away from the superficial and into the depths where people live. The pathway of peace and justice has something very personal about it. It is a pathway of solidarity, of connecting and sharing the beauty of life with all others on the pathway.

A concise look at traditional Indian community building may be helpful in establishing the kind of deportment that enabled tribal people to live with unanimity for centuries on this continent. The underlying basis for a cooperative way of life can be largely attributed to the Indian community assuming a teaching role for encouraging and assisting members to live in a harmonious way.

One example of achieving this kind of unity is the Indian people's custom of sharing with others. This act of sharing has proven to be an important way of revitalising the community and giving it new life. Sharing was an important teaching given to the children when they were at an early age. As an example Ohiyesa (Santee Sioux) states that in his tribe, 'The children must early learn the beauty of generosity. They are taught to give what they prize most, that they may taste the happiness of giving' (Nerburn \& Mengeloch, 1991, pp. 14-15).

With the emphasis on sharing, some differences as to the importance wealth plays in traditional cultures and that of modern Western societies can be seen. The modern progressive societies tend to emphasis the gaining of material wealth as important accomplishments for personal fulfilment and security. On the other hand, traditional Indian cultures did not consider their prosperity to be expressed in the accumulation of material goods for personal gain, but placed a high value on what each person could contributed to the tribe. This cooperative of human wealth had greater importance for strengthening the community.

The Cowlitz, like other tribal groups, affirmed their tribe's cohesion by resting on traditional community building practices like generosity, as mentioned above. Ouinn, in his comments on tribalism has mentioned the success that can be realised when these kinds of practices are encouraged. He states, 'Tribal wealth is the energy that members give each other in order to keep the tribe going. This energy is inexhaustible, a completely renewable resource' (Ouinn, 1997, p. 183). 
Thus, a key survival ingredient for the Cowlitz tribe during uncertain times was to fan the embers of inter-human relations, and to retain their interconnectedness with the natural environment.

This view of interconnectedness would prove to be especially important to the tribe during the time of dispersion brought about by the failed treaty session and the loss of their homeland. Tribal security would mean relying on the people's past establishment of community involvement and their resource of human wealth. When these factors were wedded with the tested endurance of the people, the tribe would be empowered to strive toward rekindling their identity from the ashes of near extinguishment.

The European intrusion into the Cowlitz homeland and the tribal community interrupted the peace and contentment that had given the people a sense of security. Before this time the Cowlitz had powerful leaders, they controlled the conduct of their own affairs, they followed the customs of their own design, and the community did not have to commit its destiny to outsiders. It was through their interdependent relationships that the Cowlitz people were able to maintain their cultural integrity and to perform their role as tribal members working together as equals. However, the loss of their land base was a major factor in forcing tribal members to be dispersed in different directions, causing their interdependence to be more difficult to maintain.

This was not the first time a major disruption faced the Cowlitz people and threatened the cohesiveness of community relations. The smallpox epidemic of 1829 was a critical test. The disease brought to the Oregon territory by Europeans was a devastating affliction to the natives who had not developed an immune response to the disease. Village residents living along the Cowlitz River were nearly annihilated as the smallpox virus spread like a wildfire throughout the region. Sir George Simpson, the Governor of Hudson's Bay Company, wrote:

When I descended the Cowlitz (River) in 1828, there was a large population along its banks; but since then the intermittent fever, which commenced its ravages in the following year, has left but few to mourn for those that fell. During the whole of our day's course, till we came upon a small camp in the evening, the shores were silent and solitary. (Simpson as cited in 'The Stranger Magazine', jacket, 1997, p. 13)

The unexpected calamity befalling the tribe threatened the individual's ability to function in the traditional tribal manner when the community was in a state of upheaval. The individual in the close-knit community setting had been dependent upon the language, oral history, story telling, rituals, and geographical sacredness of his or her tribe. The societal structure was contingent upon the collective knowledge furnished by the elders and spiritual leaders. The social structure was greatly weakened when many family members and the established leadership were stricken by disease. This left the tribal members wanting for a greater sense of cultural identity. The people's longing for community interdependence was critical since the support of others helped to overcome feelings of alienation and the loss of the cultural self.

According to Donald Fixico, traditional native people tend to see themselves in terms of 'self in society' rather than 'self and society' (Weaver, 1998, p. 39). This introspection can be viewed as having an enlarged sense of self that declares I am not only I, but we are one another or 'I am We'. Now, with the loss of land and family ties the 'We' was not as easy to distinguish since the Cowlitz tribal members found themselves struggling for survival on a more individual basis. In the struggle for greater security, apart from the whole group social structure, the separated tribal member became more solitary. Within this fragmented community, there was the possibility that the core value of the community being placed above the self would be lost. And the risk to the individual was one of being subject to isolation, loneliness, and depression.

In traditional tribal experiences, the implication of individualism would not work since interdependence was a substantial reality for acquiring personal identity. It was through their identity with the tribe that Indian people understood the true spirit of community and this in turn provided a spirit of peace within the membership. In order to avoid tribal disjunction, the individual members and clans needed to increase their efforts to effectuate greater tribal unity and to persevere in their community-building efforts.

A community achieving stability is one that is steeped in the tradition of cooperating and sharing together for the maintenance of good living. An important regard for proper living was to feel a strong allegiance toward the land and an obligation to treat it responsibly. The Cowlitz community, like other northwest coast tribal societies, learned to respect the earth as a living organism, and they realised that an intimate relationship with the planet's ecosystem was critical for sustaining their way of life. According to Catherine Keller (1998, p. 13), this broader view of community is establishing a connection to 'Every entity in the universe, and can be described as a process of interconnection with every other being. Chief Seattle of Suquamish and Duwamish heritage often spoke about the important relationship humans have and hold with the earth and the need to honour this interconnection. He said, 'Teach my children what we have taught our children - that the earth is our mother. Whatever befalls the earth befalls the sons and daughters of the earth. We did not weave the web of life; we are merely a strand in it. Whatever we do to the web, we do to ourselves' (Roberts \& Amidon, 1991, p. 10).

In the years following the Indian uprisings, the Cowlitz returned to making a living and taking care of 
their families as changing circumstance allowed. Judith W. Irwin, in her research of the Cowlitz tribe (Irwin, 1994), mentions that some Cowlitz intermarried with members of other tribes and with whites, some moved to reservations, and many remained in Cowlitz country. When the Indian Homestead Act passed in 1884, a number of Cowlitz applied for homesteads. Those who remained in Cowlitz country maintained tribal ties under the leadership of Chief Atwin Stockam. In their endeavour for survival the people were continuing to take responsibility for themselves and visioning a role of self-determination for the tribe. Coupled with these efforts was a strong sense of belonging to a land, to a people. George E. Tinker (1996, p. 121) speaks of the Indian people's relationship to the land as, 'spiritual rootedness'. For the Cowlitz, this intimate relationship to their sacred land remained deeply embedded in the people's memory. The interrelationship with the natural world and attitude of respect for the creation enabled the people to retain a purport of harmony and balance in the community.

The Cowlitz determination for keeping the community healthy was not merely for sustenance, not merely for company, but to insure that people may live with justice and peace in their lives. This intimacy with the land can have broad implications, not only for Indian people, but also for establishing justice and peace in the global community. According to Dieter Hessel (1992, p. 145), 'From an American Indian perspective, justice and peace will flow as a natural result from a genuine and appropriate concern for creation'.

Scott Peck in writing about the true meaning of community expressed a thought that was relevant to the Cowlitz situation during this time of revivification. He remarked: 'No community can expect to be in perpetual good health. What a genuine community does do, however, because it is a contemplative body, is to recognise its ill health when it occurs and quickly take appropriate action to heal itself' (1987, p. 66).

The Cowlitz recognised the need to repair their weakened social structure, and to take action for improving the conditions of community life.

Near the turn of the century, the Cowlitz, under the leadership of Chief Atwin Stockum, made a determined effort to bring tribal members together and to restore the tribe to good health. In this community endeavour, the people continued to focus on the prospect of living once again in freedom on their ancestral land as a federally acknowledged tribe. The people were pursuing the medicine power of their traditional heritage, expecting that it would bring economic and social well-being to the tribe. With this revived spirit, the Cowlitz were looking ahead for opportunities to retain and perpetuate their own Indian culture.

Following the death of Chief Stockum in 1912, the Cowlitz reorganised their tribal government by changing to a different form of leadership. An elected chairman and tribal council replaced the traditional position of chief. The new tribal leadership began taking legal measures for obtaining compensation for land that was unjustly taken from them. From 1915 until 1927, a total of thirteen bills were introduced by the Cowlitz to Congress, seeking compensation for lost lands. Some of the bills passed the House, some passed the Senate, one was vetoed by President Coolidge, and most died in committee. The tribe had patiently and systematically pursued their quest for justice, only to come up empty handed once again.

\section{Hope - Keeping Faith During Difficult Times}

The experience of the Cowlitz people is an attestation that life is an endless cycle of change. Contact with Europeans had thrust the Cowlitz tribe into a rapidly changing world. The past experiences of having to make numerous changes throughout its history conditioned the people to continue evaluating and modifying its culture in order to adjust to the disappointments brought about by those changes. With the difficult situations facing them the people realised that failure to make adaptations could lead to social disorganisation, total integration, or exploitation by a more aggressive and rapidly developing culture.

Teedyuscung, an elder of the Delaware nation, in responding to the difficulties resulting from the European invasion of his people's homeland, passed on words of wisdom, kinship and hope to other tribes who were to face similar hardships. He said:

\begin{abstract}
When you begin a great work you can't expect to finish it all at once; therefore you and your brothers press on, and let nothing discourage you till you have entirely finished what you have begun. Now, Brother, as for me, I assure you I will press on, and the contrary winds may blow strong in my face, yet I will go forward and never turn back, and continue to press forward until I have finished, and I would have you do the same. Though you may hear birds singing on this side and that side, you must not take notice of that, but hear me when I speak to you, and take it to heart, for you may always depend that what I says shall be true' (Neburn \& Mengeloch, 1991, p. 25-26)
\end{abstract}

The Cowlitz were ready to press forward for they had earned the reputation of being a powerful nation with prominent leadership capabilities. They were renowned for their expert horsemanship, hunting proficiency, and their ability to prosper on the prairie and river. The Cowlitz were ready to press forward for they had earned the reputation of being a powerful nation with prominent leadership capabilities. They were renowned for their expert horsemanship, hunting proficiency, and their ability to prosper on the prairie and river. In his testimony before a Congressional Hearing on April 1978, Joseph Cloquet referred to a statement made by Special Indian Agent Charles E Roblin. The comment by Roblin, in 1919, was an acknowledgment of the high respect being ascribed to the Cowlitz people. He said 
that 'the Cowlitz Tribe. He said that 'The Cowlitz Tribe was a powerful tribe, and in the early days constituted the "blue blood" of Western Washington. They were independent, fearless, and aggressive. Their descendents have the same qualities which placed their ancestors in the position of leaders' (Cloquet, 1978, p. 24).

The qualities mentioned by Agent Roblin remained ingrained in the generations who were following in the footsteps of their ancestors. These worthy attributes of the Cowlitz people would be sorely tested in the days ahead, as they put forth efforts to obtain payment for their land, and to become acknowledged as a tribe. And this would prove to be a long and arduous part of their journey for cultural survival. The tribe was facing a symbolic catch-22 predicament. The Department of the Interior was telling the Cowlitz they could not be federally recognised by the government unless they had a land base, and they could not have a land base unless they were federally recognised. This logic prevailed for many years and was an ablation on the hope the tribe had been maintaining in the long uphill struggle of waiting for the government's justice system to treat them fairly.

Despite the uphill struggle, hope refused to die, but sprang anew. In 1973, the Cowlitz tribe brought a land claims settlement before the Indian Claims Commission. After debating the Cowlitz claim, the government appropriated funds to pay a judgment to the tribe for land taken in 1863 by the United States without treaty or compensation. The Cowlitz reluctantly accepted the settlement because to them the judgment amount lacked a fair market value and seemed demeaning. The Indian Claims Commission awarded \$1,550,000 for 1,790,00 acres of the Cowlitz aboriginal land base. This settlement of roughly 90 cents per acre ended up being a fraction of what the land was worth. The tribe felt that they had compromised to the full extent of their ability without losing everything for the people. Left with no further recourse, the tribe considered the matter of how the general membership wished to have the judgment funds distributed.

In compliance with P.L. 93-134, a provision for use or distribution of funds appropriated by the Indian Claims Commission and the Court of Claims, the Cowlitz tribe presented their plan for distribution to the Secretary of the Interior. The plan was carefully drafted with the assistance of the Department of the Interior and was unanimously supported by the tribal membership. Unbeknownst to the Cowlitz, on November 4, 1974 the Department of the Interior, under the direction of the Secretary of the Interior, submitted to Congress an alternative plan for the distribution of the judgment funds. The Secretary's plan for distribution was diametrically opposed to the plan submitted by the Cowlitz tribe. Fortunately, a Cowlitz tribal member happened to read the announcement regarding the Cowlitz distribution of funds in a publication of the neighbouring Yakima Tribe.
A notification of the Secretary's plan was not given to the Cowlitz, either by the Department of the Interior or Bureau of Indian Affairs (BIA), until it was almost too late to act upon it. When the tribe did hear about the Secretary's plan, there was only a 30 -day period before it became law. The Cowlitz Tribal Council took immediate action and the Secretary of the Interior withdrew his plan - another injustice narrowly avoided.

A request by the Cowlitz Tribe to have a portion of the judgment fund set aside for the purchase of land failed to meet approval by the 94th Congress. The tribe had their Distribution of Funds Appropriated Bill reintroduced to the 95th Congress, asking that $20 \%$ of the funds appropriated be used for the purchase of land prior to per capita distribution. The request to set aside funds for land purchase was intended to help preserve tribal entity, tribal ties, tribal language, and the culture that had been denied over the past century. Cowlitz chairman Joseph Cloquet, testifying on behalf of H.R. 5523 before a House Congressional Committee On Interior and Insular Affairs, stated the case for his tribe's acquisition of land:

I cannot stand by and see my people disband forever. Without land, our gentle people, who welcomed the white man to our fruitful prairies, forests, mountains, and streams, in the most beautiful country on earth, and even fought on their side during the Indian Wars, will become a footnote to history. Genocide of a race, a culture and a language will be inevitable (Cloquet, 1978, p.10)

The Congress seemed to have little objection to the bills presented by the Cowlitz except the request for a portion of the funds to purchase land and to be held in trust for the tribe. This request was denied. The Cowlitz was informed that being a landless tribe they were able to receive an Indian Claims Commission Judgement Award only by per capita distribution. These funds would be distributed to all Cowlitz descendants regardless of blood quantum or tribal enrolment and not any portion to the tribe as a whole or for the purchase of land. The government had failed to understand that Indian people's traditional wisdom cautioned them to put aside part of their resources for difficult times and not to deplete them all at one time. Further, the government agencies neglected to realise that in the traditional community it was commonplace for people to work together as 'We' and by distributing on a per capita basis, it would promote greater individualism thus breaking down tribal unity. Finally, the federal powers were unable to see that the Cowlitz were not seeking to put individual interests first, but they were desiring that a portion of the distribution be for the good of the entire tribe and its future. Given the government's decision the Cowlitz decided not to pursue having the judgment funds distributed for the time being and allowed it to remain in the US Treasury earning interest. They would seek Federal acknowledgment and then take up distribution matters with Congress when they had achieved that goal. 
The government would then have to transact with the tribe on a different premise. Little did they realise how long the process would take to complete. They were to find out, once again, that the government's wheels of justice grind slowly.

In 1978 the Cowlitz petitioned the Secretary of Interior requesting that a review be conducted to determine whether the tribe was entitled to be acknowledged as an Indian tribe. A special office of the (BIA), known as the Branch of Acknowledgement and Research (BAR), judged the tribe's application on the basis of seven Recognition Regulations applicant tribes had to meet in order to be recognised. One of the regulations for federal acknowledgment required the tribe to establish that the Cowlitz people continued to be a tribe. This meant that the tribe had to demonstrate they still existed as a viable tribal entity and not simply descendents of Cowlitz Indians. Other regulations needed evidence demonstrating the tribe's continued existence as an Indian community and that a substantial portion of the tribe inhabited a specific region. Furthermore, the tribe had to show proof it had been identified as a separate group of people in the past, and that it had maintained social and other contacts among its members on a regular basis up until the present. An additional condition of the regulations called for the tribe to document when members met to discuss and resolve matters requiring collective action concerning the tribe or its members.

The Cowlitz felt confident that they could meet these criteria; however, BAR would be a difficult body to convince since they had a strong predilection to recognise as few tribes as possible. Also, as in the case of other tribes seeking acknowledgment, the Cowlitz would be judged very strictly in the fulfillment of each requirement.

The acknowledgment process became like a paper game for the tribe. In it's attempt to meet the changing guidelines for supporting evidence and verification of factual statements the tribe had compiled more than 3,000 pages of documentation to meet the BAR criteria for existence. Five years from the initial filing of the petition with the Secretary of the Interior, tribal Chairman, Roy Wilson reported that the fifth draft of the acknowledgment petition was being submitted. Again, under Chairman John Barnett, additional work was required in 1988 to strengthen the historical documents asked for by the petition reviewers. And again, in 1990, the tribe was forced to completely rewrite parts of their petition in order to comply with a new series of questions proposed by BAR. Dr Stephan Beckham took on the tremendous task in 1993 to rewrite the Cowlitz acknowledgment petition to be forwarded to BAR with the hope this would be the final draft. At this rate, it seemed like it would take a forest to supply enough paper to meet the government's demands.

The Federal Acknowledgement Petition was submitted once again on February 24, 1994, but the tribe was informed that it would not be reviewed until the spring of 1995. At that time there was uncertainty as to whether the petition would be reviewed under the old set of criteria or under a new set recently adopted. What the Cowlitz people were learning, in their pursuit of justice, was that they needed to keep their feet on the path of wisdom, unity and hope, upon which their ancestors had walked for centuries. The tribe metaphorically took a deep breath, straightened up, gritted teeth, and reached high like the curling smoke from former village fires. The anticipation was that with a new administration in the White House, there would be greater concerns shown for working with unrecognised Indian tribes.

In the summer of 1995, the Cowlitz Tribe came under active consideration in the BAR process. A review team was scheduled to come to Cowlitz Country to meet with the Tribal Council, individual Cowlitz members, neighbouring tribes, and the local BIA staff. The reviewers would thoroughly examine the tribal office and the Cowlitz tribal records. The tribe was heartened by the personal attention given by the BAR team and there was excitement over the expectation that a determination of the tribe's status could be made shortly.

The 'Final Determination' published in the Federal Register on February 14, 2000 concluded that the Cowlitz Tribe met the mandatory criteria for Federal acknowledgment of Indian Tribes. The Quinault Indian Nation was not in favour of the Cowlitz tribe being recognised and they filed a request for reconsideration on the basis that the Cowlitz had not fully met the necessary requirements. The Quinaults also may have had concerns about the Cowlitz residing on the Quinault Reservation usurping authority away from the Quinault's current leadership position if the Cowlitz tribe was given federal recognition. Their effort to overturn the Cowlitz Final Determination decision did not succeed since they could not support their objections. Finally, Neal A. McCaleb serving as The Assistant Secretary of Indian Affairs, signed a reconsideration of final determination on January 4, 2002 which affirmed the decision of February 14, 2000, acknowledging, 'that the Cowlitz tribe exists as an Indian tribe within the meaning of Federal Law'. As stated by tribal Chairman John Barnett in a Seattle newspaper article: 'After all these years, justice has finally been done. We're not extinct. They are finally recognising that we've always been here and always been an historic tribe' (Shukovsky, January 4, 2002, p. B.2.).

\section{Conclusion}

The journey we have taken with the Cowlitz Nation has revealed a people who have demonstrated respect for the past, have been able to endure changes, and are capable of making provision for future survival. The collected wisdom of past generations has been put into practice to facilitate changes that have enabled the people to exist. The medicine power provided strength for interdepen- 
dent living, thereby contributing to the health of the community and to the survival of the natural world. The journey of the Cowlitz people has been one of reaching for the light, toward justice and peace: a people who confronted injustice and prevailed - a people who had a vision of living again in ancestral lands in peace, and have found that light.

The land claims settlement and federal acknowledgment has made it possible for the Cowlitz tribe to maintain its cultural identity and to provide security for its members. As a result the Cowlitz have been able to acquire land that has family roots going back thousands of years; a land surrounded with the spirits of family members who have left their footprints. Having established a land base once again, the Cowlitz tribe can now use its energies to successfully participate as a modern Indian tribe in the mainstream of American culture. While the Cowlitz continues to hold to the traditions of the past, they are an ardent and capable people seeking to secure a place for themselves, and for future generations, in the current global community.

Several thoughts emerge from our journey that can be useful in the search for additional paradigms of justice and peace. The Cowlitz have shown that by employing the collective wisdom of those who have gone before and augmenting this seasoned knowledge with new understandings, they can make things happen to better their lives. The wise words of Chief Dan George are good council regarding efforts to blaze new pathways and yet having an awareness of footsteps from the past. He has said to his people and to others who will listen: 'In the midst of a land without silence you have to make a place for yourself. Those who have worn out their shoes many times know where to step. It is not their shoes you can wear only their footsteps you may follow — if you let it happen' (1974, p. 13).

Establishing a community of justice where all people are treated as equals is a virtuous pathway that transcends self-centeredness and seeks the well-being of every community member. The Cowlitz people came together as a community and viewed one another as vital units of the tribe. They learned the value of sharing and being generous with one another during the good and difficult times. In the spirit of camaraderie the people came to discover the contentment that the cultural historian, Thomas Berry, later referred to in his remarks at the UN Millennium World Peace Summit for Religious and Spiritual Leaders. Berry stated: 'Perhaps our greatest resource for peace is an awareness that we enrich ourselves when we share our possessions with others. We discover peace when we learn to esteem those goods whereby we benefit ourselves in proportion as we give them to others' (August, 2000).

In the wisdom of Indian people we are reminded that there are indissoluble links between human health and that of the natural world. In the Indian tradition, the proper role of humankind is obedience toward the natural world and service toward the environment that gives them life. In striving for better lives, people often overlook the important privilege of our living in a healthy environment - a right that belongs to everyone. As citizens of an industrial society, we must begin to challenge ourselves to be better stewards of the natural world for the benefit of all, including the generations to come. The survival of the Earth is a moral issue that requires everyone to come together and join hands for maintaining a just and sustainable planet.

The Cowlitz tribe was able to achieve the goal of overcoming injustice and obtaining the peace of locating again in their aboriginal lands by capturing the medicine spirit of wisdom, community, and hope. These components have served as the true measure of the Cowlitz wealth. By clinging to a vision of hope, the people patiently came to realise their goals through an arduous step-by-step process. What can be learned from their efforts is that it is important to have a vision and a plan for peace and justice in our communities, and that the seed of this reality lies within each of us to be spread beyond our lives to the global community. The choices faced by individuals on the pathway of right relationship are the same choices societies and nations face, that is to awaken to a vision of mutual interdependence and participation that ensures that all the people may live together in greater peace and justice.

\section{References}

Bellah, R.N. (1989). The search for meaning in modern America. In J.J. Macionis, \& N.V. Banokraitis (Eds.), Seeing ourselves (pp. 449-70). Mahwah, NJ: Prentice Hall.

Berkedal, C. (1998, March 1). Native American voices: Two recent gifts. Earth Letter Journal.

Cloquet, J.E. (1978). Testimony given during the Congressional Hearing on H.R. 5523, regarding a bill to provide for the distribution of funds appropriated to pay a judgment in favour of the Cowlitz Tribe of Indians, United States House of Representatives, April 4, 1978.

Cowlitz Indian Tribe (2006). The Cowlitz Indian Tribe: Past and present. Longview, WA: Author.

George, D. (1974). My heart soars. Vancouver, BC: Hancock House.

Hessel, D.T. (1992). After nature's revolt. Minneapolis: Augsburg Fortress Press.

Irwin, J.W. (1994). The Cowlitz Indians in the Cowlitz corridor. Columbia Magazine, 8, 10-15.

Jacket, B. (1997). Back from extinction. The Stranger Magazine, 6,33 .

Keller, C. (1998, March 13). From a broken web. Earth Letter Journal.

Nerburn, K., \& Mengeloch, L. (1991). Native American wisdom. Novato, CA: New World Library. 
Peck, M.S. (1987). The different drummer. New York: Simon \& Schuster.

Quinn, D. (1997). My Ishmael. New York: Bantam Press.

Quinn, D. (1999). Beyond civilization. New York: Three Rivers Press.

Roberts, E., \& Amidon, E. (Eds.). (1991) Earth prayers: from around the world. San Francisco, CA: Harper.

Shukovsky, P. (2002, January). Cowlitz tribe gains Federal recognition. Seattle Post Intelligencer, p. 3.
Tinker, G.E. (1996). Spirituality, Native American personhood, sovereignty, and solidarity. In J. Treat (Ed.), Native and Christian (pp. 121-124). New York: Routledge.

Weaver, J. (1998) Native American religious identity. New York: Orbis Books.

Wright, R.K. (1991). A time of gathering: native heritage in Washington State. Seattle, WA: University of Washington Press. 